Book chapter in The SAGE Handbook of Political Science Edited by Bertrand Badie, Dirk BergSchlosser, and Leonardo Morlino. (forthcoming in 2019)

\title{
Human rights and humanitarian interventions on the international arena
}

\author{
Salvador Santino Fulo Regilme Jr: \\ University Lecturer of International Relations \\ History and International Studies, Institute for History \\ University of Leiden, The Netherlands \\ s.s.regilme@hum.leidenuniv.nl
}

\section{Introduction: conceptualizing human rights and humanitarian interventions}

The proliferation of human rights discourses in contemporary global politics is remarkable. The ongoing, multi-sided civil war in Syria is probably the largest humanitarian man-made disaster since the end of World War 2. Close to half-a-million people died because of the violence therein, while at least a million refugees have fled the country in search for a better life elsewhere. The rights of refugees and civilian victims of the conflict figured quite prominently in debates on whether the US government, among other countries in the Global North, should militarily intervene in Syria in order to prevent further escalation of violence. Responding to the Syrian crisis in its early phase in 2012 and 2013, key officials in the administration of the US President Barack Obama-including Anne-Marie Slaughter, a notable International Relations scholar and then Director of Policy Planning at the State Departmentadvocated for American military intervention even to the extent of bypassing UN Security Council's approval. In general, intervention advocates posit that militaristic means are necessary in order to prevent a murderous regime, as it is the case in Syria, from further killing civilians an argument that intends to uphold the right to life of innocent civilians. Oppositionists, meanwhile, argue that humanitarian interventions often strategically use rights discourses not primarily to protect innocent civilians but to promote geostrategic military and economic interests of the intervenors. The case of Syria represents a key puzzle in contemporary world politics: the normative principles, political foundations, and consequences of the global human rights regime and humanitarian interventions.

Considering that context, this chapter provides an analytic overview of one of the most important developments in contemporary world politics: international human rights norms and humanitarian interventions. What constitute international human rights norms? What constitutes a humanitarian intervention? How are human rights related to humanitarian interventions?

The notion of international human rights refers to various legally and politically sanctioned entitlements that are conceived to be inherent to all human individuals regardless of their national origins, residential status, gender, linguistic heritage, or any other forms of identity affiliations, external characteristics, and personal background. The United Nation's Office of the High Commissioner for Human Rights posits that such rights can be found in numerous forms of

\footnotetext{
* Salvador Santino Fulo Regilme Jr (born 1986) is a tenured University Lecturer of International Relations at the Institute for History, Leiden University. He is the co-editor of American Hegemony and the Rise of Emerging Powers (Routledge, 2017) and the author of peer-reviewed articles in International Studies Perspectives, Third World Quarterly, International Political Science Review, among many others. He received in 2015 his joint PhD in Political Science and North American Studies from the Freie Universität Berlin and previously studied at Yale, Osnabrück, and Göttingen. His current book project is tentatively titled Philanthropic Imperium: United States Foreign Aid, Diplomacy, and Human Rights.
} 
international treaties, customary public and private international law, national constitutions, regional declarations, and many other sources of international law.

Accordingly, human rights have several quintessential features. First, international human rights are universal to the extent that every individual possesses them regardless of their location, personal background, and nationality - although, there is some variation as to which specific rights are legally protected depending on which human rights treaties did the relevant state has fully ratified. Also, human rights are inalienable to the extent that they are not supposed to be discredited or suspended arbitrarily except when due process and legally sanctioned rules have been followed. The notions of equality and non-discrimination constitute key principles of international human rights, whereby no human being should be hindered from enjoying their rights on the basis of group affiliation and other backgrounds. In international law, states take the ultimate responsibility in ensuring that individual human rights are fully protected within its borders, and by implication, individual human beings are also responsible for respecting the rights of their fellow individuals.

The common public understanding about human rights suggest that such norms evolve over three historical generations of rights: (1) civil and political; (2) social and economic; and, (3) group and collective rights. Originally proposed by Czech jurist Karel Vasak in 1979, the 'Three Generations of Rights' theory have gained traction in global politics because of a variety of reasons, which includes its apparent simplicity of categorizing rights in terms of the types of privileges that can be extracted from such legal entitlements. Yet, the historian Steve Jensen (2017) contests the 'Three Generations of Rights' perspective because of several compelling arguments. The first reason pertains to its unclear historical periodization of the emergence of each rights category. Particularly, there is no convincing historical basis for Vasak's post-1945 framing, which links the 1948 Universal Declaration of Human Rights with the two other Covenants from 1966. Also, Vasak's framing does not accurately reflect a linear evolution of human rights contestations, as Vasak later on revised his argument by tracing three generations to the French Revolution's notions of liberty, equality, and fraternity. As Jensen accurately notes, socio-economic rights are mutually constitutive with civil and political rights as demonstrated by the history of French Revolution and consequent human rights struggles. Hence, human rights history should be conceived as complex and contentious politics, with various demands from a variety of actors across historical time and political space - rather than a neat line of progressive political demands, as suggested by the 'Three Generations of Rights' theory.

The substantive content and justifications for international human rights vary depending on the analytic perspective that one might use (Macklem 2015). In the field of moral theory, human rights function as natural entitlements to all individuals by the virtue of one's humanity. The right to be free from physical harassment and torture, accordingly, is a natural right that all human individuals possess regardless of their political, legal, and social status. In other words, human rights precede any form of state-based socio-legal infrastructure or even international legal system. The political theory view maintains that human rights are not natural entitlements; rather, rights function as discursive concepts deployed in transnational politics in ways that represent contentious struggles amongst various actors over global public goods. States, for instance, instrumentalize human rights values in order to justify various forms of interventions over other states. More recently, in international politics, the demand for human rights protection sometimes serves as justificatory premises for violating the notion of state sovereignty, as clearly demonstrated in humanitarian intervention debates. Specifically, such a case can also be seen when Western states justify foreign aid programs in recipient states in the Global South, or when the Bush administration justified its militaristic approach to the US-led global war on terror as a means to promote democracy and human rights in supposedly conflict-ridden states (Regilme $2018 \mathrm{a} \& b)$. To be sure, it is not only states that appropriate human rights for their own geostrategic and violent goals; as Nicola Perugini and Neve Gordon (2015) maintain, Israeli settler NGOs apparently instrumentalized human rights in order to disenfranchise Palestinians 
while military think tanks invoke rights discourses as they justify political violence. Lastly, from a legal positivist perspective of international law, the legitimacy of human rights norms comes from constituent elements of international law upon which states have committed to. For example, the right of the person to be free from torture and any form of cruel and degrading treatment is a well-established human rights norm because of the 1985 United Nations Convention against Torture, an important international human rights treaty with 164 state parties as of June 2018.

What exactly counts as a humanitarian intervention? Whereas human rights often refer to the broad set of principles that seek to protect the welfare of individual human beings, humanitarian interventions, meanwhile, pertain to a particular set of actions that frequently invoke human rights discourses in order to intervene in the internal affairs of another state. Essentially, humanitarian interventions refer to a set of coercive and non-coercive actions that aim to interfere in the domestic affairs of a state with the core purpose of averting or minimizing severe and pervasive human rights abuses (Welsh 2004, 3). The historians Brendan Simms and D.J.B. Trim $(2011,4-5)$ provide a simple yet fairly useful list of the key elements that constitute a humanitarian intervention. First, its main purpose is to shape events and actions within another state or a group of states or another geographical regional. Second, such a form of intervention primarily aims to influence or shape the behavior of the government of the target state(s). Thus, humanitarian interventions are generally coercive, although each case of intervention may involve various methods of coercion that range from purely diplomatic means to threats and actual use of force and violence. Finally, the core aim of humanitarian interventions is to prevent or to stop the emergence and recurrence of high levels of mortality, mass violence, severe human rights violations, and other forms of prevalent suffering as perceived to be caused by the action or lack thereof of the ruling authorities in the target state(s) or region.

In International Relations literature, humanitarian intervention often only constitutes militaristic and coercive means (Welsh 2004, 3; Newman 2009, 3-4), but one must note that interventions often include an aggregate variety of methods. As Trimm and Simms (2011, 6-7) maintain, humanitarian intervention demonstrates an interesting relationship between coercion and diplomacy as methods of influence. Accordingly, diplomatic means usually precede the implementation of militaristic and coercive means. When an extremely repressive state halts its violent actions, it is likely the case that an intervening state had threatened the prospect of using military force beforehand. In some cases, an intervening state may have deployed armed forces that did not result into an escalation of hostilities. For those reasons, it is more conceptually accurate to consider a wide range of diplomatic and coercive methods as constitutive forms of humanitarian intervention instead of limiting the analysis to militaristic approach as what Jennifer Welsh and others (2004) did in an influential volume on the topic.

Having set out what is being conceptualized as human rights and humanitarian interventions are, this chapter proceeds with the following organizational logic. First, the following section provides an analytic outline of the historical origins of international human rights norms and human rights interventions. Second, the chapter discusses the various scholarly views pertaining to the most critical factors that shape the patterns of human rights compliance and violations. Next, the chapter explores the underlying legal principles and ethical foundations of the norm of humanitarian intervention as well the contending views in support of and in opposition to such a norm. The penultimate part of the chapter, meanwhile, presents some of the most quintessential issues pertaining to the global human rights regime, with a particular focus on the rise of illiberal and authoritarian regimes, sharply increasing material inequality, and the rights to privacy in the age of continued digitalization. This chapter concludes by raising some important questions in regard to the future of social science-based scholarship on human rights and humanitarian interventions. 


\section{Historical origins of the global human rights and humanitarian interventions}

Since the end of the Second World War, international human rights norms have gained traction not only in the political discourses of state leaders and civil society activists, but perhaps, more importantly, in the codified documents of international law. How did human rights emerge as a well-entrenched principle in international law?

The history of the contemporary international human rights regime can be traced from various perspectives. For instance, the political theorist Jean Cohen (2008, 579-580) contends that the initial push to reinvigorate human rights in the contemporary period emerged in the wake of the severe human suffering committed by imperial powers against unarmed individuals during World War II(Cohen 2008). Meanwhile, the historian Elizabeth Borgwardt (2007) maintains that the US presidential administration of Franklin Roosevelt played a pivotal role in spearheading the human rights revolution that has underpinned the current world order. Particularly, Roosevelt's role in the 1941 Atlantic Charter and the "Four Freedoms" functioned as path-breaking international pronouncements that powerfully emphasized the rights and welfare of people rather than the interests of nation-states (Jensen 2016, 23). Based on the underlying principles of the Atlantic Charter, the United Nations (UN) Charter and Statute of the International Court of Justice (1945) reaffirmed the importance of "fundamental human rights, in the dignity and worth of the human person, in the equal rights of men and women and of nations large and small" (page 1). Yet, small states and civil society organizations should be emphasized as the most outspoken and pioneering advocates of human rights at a time when the post-1945 world order was at its earlier phase of emergence. In fact, around 42 American and international civil society organizations participated in the 1945 San Francisco convention that eventually created the UN and the joint and persistent lobbying initiatives eventually facilitated the Human Rights Commission (Waltz 2002, 441).

More recently, Steve Jensen (2016) maintains that the international human rights revolution began in the 1960 s to the 1970 s, when international activists and states started to imbibe human rights in their discourses . Notably, Jensen compellingly shows that the history of human rights has inaccurately privileged Western agency, and he instead demonstrates that a core group of non-Western states (Liberia, Philippines, Jamaica, and Ghana) pushed for human rights in international diplomacy in the 1960s in the context of decolonization. Although the UN Charter and the Universal Declaration of Human Rights emerged with the leadership of the West, the universal nature of these documents is highly contested. As Jensen argues $(2016,3)$, "in the hierarchical world of empire, human rights had only a limited opportunity to shape global politics", primarily because the notion of universality is inherently antithetical to such an international system. After the decolonization of many states in the Global South, a more universalist conception of human rights gained traction as discourses and negotiations occurred in an international system where formal empires no longer exist. For example, diplomats from the Global South states pushed for a more inclusive conception of human rights with a focus on racial equality and religious freedom. Arguably, the Convention on Elimination of All Forms of Racial Discrimination emerged as the first document of international law that explicitly embraces and extensively addresses the committed protection of the dignity of all human persons regardless of racial background.

In contemporary public international law, various human rights principles are fully entrenched in the International Bill of Human Rights, which is constituted by three landmark documents: (1) UN Declaration of Human Rights (UDHR) /1948; (2) the International Covenant on Civil and Political Rights (ICCPR) / 1966; and, (3) the International Covenant on Economic, Social, and Cultural Rights (ICESCR)/ 1966. The UDHR constitutes thirty provisions that explicitly maintain an individual's rights, with the emphasis on the right to life and the prohibition of slavery, among other human rights specification. It is also the first step towards the formation of the International Bill of Human Rights. The ICCPR, meanwhile, highlights 
those rights that enable individuals to fully participate in the political community, including the freedom of speech, assembly, right to due process and fair trial, and the right to vote. The ICESCR specifies those rights that protect the dignity of the human person as one participates in the social, cultural, and economic systems; such rights include labour rights, healthcare rights, and the right to education, among others. Since the introduction of these documents, human rights principles have continued to be embedded in various conventions at various levels of constitutional order, ranging from the domestic, regional, and international dimensions (Hopgood 2014, 67). For instance, there are conventions on discrimination against women (1981), torture and degrading punishment (1984), children's rights (1989), rights of migrant workers and their families (1990), the protection of all persons from enforced disappearances (2006), and disability rights (2006). At the regional level, several important documents emerged as part of a broader commitment to human rights: the African Charter on Human and Peoples' Rights (1986); American Convention on Human Rights (1978); Charter of the Fundamental Rights of the European Union (2000); Arab Charter on Human Rights (2004); and, the Association of Southeast Asian Nations (ASEAN) Human Rights Declaration (2012). These documents that were formed at the regional level are significant amidst efforts of some Global South politicians to undermine civil and political rights as a necessary strategy to build social cohesion and long-term economic development. For instance, the ASEAN Human Rights Declaration concretely undermines the arguments of Singapore's Lee Kuan Yew and Malaysia's Mahathir Mohammad, who remained active during the East Asian values debate in the 1990s as they legitimize the repression of peaceful political dissidence by referring to its promised longterm economic benefits.

Amidst the proliferation of human rights instruments, it is still not clear whether international human rights law effectively deters state abuses - although Beth Simmons (2012) maintains that the state's treaty commitments are more likely to facilitate the emergence of a political environment that is compliant with human rights (Simmons 2009). Simmons, however, admits that her study only shows the correlation of treaty commitments with improved human rights practices, and she acknowledges that human rights violations often emerge from a complex set of structural domestic political and economic conditions. Similarly, another study confirms that these international human rights instruments often function as "window dressing" for signatory states, although transnational activists invoke such rights to mobilize action against abusive regimes (Tsutsui and Hafner-Burton 2005). Regardless of its effect on actual human rights outcomes, the proliferation of human rights instruments in international law constitutes a fundamental challenge to the norm of state sovereignty.

Meanwhile, humanitarian interventions presuppose three constitutive elements: (1) interventionist politics that violate state sovereignty norm; (2) ethical considerations on the legitimate conditions for militaristic or coercive interventions, particularly in the context of just war debates; (3) and, human rights of those whose are supposed to benefit from such an intervention. Although the derivative yet fairly similar concept such as 'responsibility to protect' is very new, the concept and practice of humanitarian interventions enjoy a long history (Klose 2015; Simms and Trim 2011). The anthropologist Didier Fassin (2013) contextualizes militaristic and non-militaristic interventions in the name of 'humanity' - as part of the emergence of what he calls as the humanitarian reason during the late twentieth and twenty first centuries (Fassin 2012). This mode of normative reasoning points us to the mutually shared feelings of empathy for the suffering of other individuals, thereby invoking the predisposition to alleviate suffering often through extraordinary means such as coercive and militaristic interventionist policies - a mode of governance that now pervasively regulates and justifies the inevitable presence of vulnerable individuals. Disputing the conventional belief that humanitarian interventions only emerged by the end of the Cold War, the historian Davide Rodogno (2011) uncovers the European origins of such a concept by examining the British and French interventions in the Ottoman Empire during the nineteenth century. This particular 
historical marking as the genesis of humanitarian intervention supports the view of Trim and Simms $(2011,10-11)$ in their edited volume, whereby they opposed the argument of Gary Bass' pioneering work on this topic by referring to the 1820s Greek Revolt against the Ottoman Empire - the first $19^{\text {th }}$ century European intervention that can be rightfully acknowledged as an intervention deliberately legitimated by humanitarian reasoning.

In contrast, although humanitarian interventions have existed even before the 1990s, the post-Cold War forms of interference are notably different based on two specific features (Ayoob 2002, 83). The first feature pertains to its invoked purposes. Whereas pre-Cold War interventions were unashamedly justified as political and geostrategic by nature, interventions in the 1990s predominantly constitute universalistic and humanitarian reasons. The second feature refers to the political actors that deploy the interventions. Various post-Cold War interventions usually require a coalition of states acting on behalf of the international community instead of acting on their own interests.

The post-Cold War era has witnessed the increase in the invocation of Chapter VII of the United Nations Charter, whereby 93 percent of all Chapter VII resolutions passed by the UN Security Council during the period 1946 to 2002 were all approved after the early 1990s (Walling 2015, 392). This finding demonstrates how the post-Cold War global security environment entailed a lot more intra-state problems with transformative regional security effects. These domestic state security problems constitute one of the key challenges for the UN Security Council, which needs to address the conflict between the norm of state sovereignty through non-interference versus human rights protection through humanitarian intervention.

\section{Scholarly views: factors that shape human rights outcome $(2,500$ words $)$}

The current political science debate on the factors and conditions that shape human rights outcomes can be broadly divided into two notable clusters: international relations (IR) and comparative politics (Regilme 2014b). The key difference between these two clusters lies on their level of analysis where explanatory variables can be extrapolated to understand a particular human rights outcome. Whereas comparative politics highlights the role of intra-national and domestic variables, IR, meanwhile, emphasizes the causal power of transnational factors.

In the field of IR, there are several influential studies that have substantially influenced our scholarly understanding of the factors that shape human rights outcomes. Perhaps the pioneering body of scholarly works on that regard emerged in the 1990s, after the Cold War era, when social constructivist analytic approaches and qualitative methods were predominantly used in order to examine the role of human rights norms in actual politics and public policy. One of these works is Activists Beyond Borders (Keck and Sikkink, 1998), which proposes the 'boomerang pattern' of transnational activist coalition-building strategy(Keck \& Sikkink 1998). In such a strategy, domestic civil society organizations form alliances with their transnational counterparts in order to jointly press an abusive government towards a more human rightscompliant policy approach. For example, Keck and Sikkink (1998) refer to several case studies of coalition-building, including the policy area of environmental protection as shown by the transnational partnerships of civil society organizations (e.g. Greenpeace and the World Wildlife Fund) to undermine deforestation in the Brazilian Amazon and the Sarawak region in Malaysia. This transnational network could further amplify pressure upon abusive states by calling in the support from various stakeholders at the global level. Part of this constructivist agenda on human rights research is Thomas Risse and colleagues' The Power of Human Rights (1998), which proposes the five-stage spiral model of human rights compliance(Risse et al. 1999; Risse et al. 2013). Such a model constitutes the various socialization processes and causal mechanisms that abusive states undergo as they eventually internalize and practice human rights norms. Perhaps the most recent and notable study on the rise of human rights norms is Kathryn 
Sikkink's The Justice Cascade (2011), which pertains to the transformative norm in international politics that holds individual government officials, state agents, and others as criminally accountable for human rights abuses(Sikkink \& Kim 2013; Sikkink 2011). Analyzing a wide variety of qualitative and quantitative evidence through the lens of agency-oriented constructivism, Sikkink maintains that the emergence and effectiveness of a human rights norm can be attributed to the persistent advocacy work of states and transnational nongovernmental organizations that sought to institutionalize criminal accountability for human rights abuses. More recently, Salvador Santino Regilme (2018a\&b; 2015) maintains that foreign aid and the converging interests and discourses of donor and recipient government shape the ways through which those resources could be primarily used either for the violent repression of all forms of dissidence or for democracy and human rights promotion. For instance, the Thai government, under the leadership of Prime Minister Thaksin Shinawatra (2001-2006), actively cooperated with the Bush administration in the US-led war on terror, consequently repressed many forms of peaceful dissidence, and killed civilians by actively reframing the illegal drugs problem and political opposition members as terror threats.

Another influential perspective, meanwhile, on human rights compliance pertains to the realist perspective, which highlights the role of enduring national interests as the key predictor for states' behavior. Accordingly, the effects of human rights instruments (e.g. international law, regional human rights mechanisms, etc.) are at best epiphenomenal, and states ratify those instruments (and comply with human rights norms) when it is in their best national interest to effectively respond to the organized demands articulated by international activists and stakeholders. The realist view on human rights attempts to refute social constructivism's claim that human rights norms exert causal power upon the behavior of political actors as well as interstate diplomacy. Stephen Krasner (2010) argues that the core interests of the most economically and military powerful countries of the international system are reflected in the way human rights-oriented issues are talked about across historical time. In that way, powerful states often instrumentalize human rights discourses in order to justify interventionist and perhaps coercive foreign policies towards less powerful states (Measheimer 1994/1995; Downs, Rocke, and Barsoom 1996).

Furthermore, the liberal institutionalist human rights literature acknowledges the powerful role of national interests as a key influence but acknowledges that, under certain conditions, states may still comply with human rights norms as promoted by global governance institutions and the international legal system. The liberal institutionalist perspective dismisses the realism's core assumption that world politics is ultimately about the enduring struggle for power amongst competing states; instead, liberal institutionalism highlights the possibility of cooperation amongst states through the maximization of gains through international institutions. Robert Keohane and Joseph Nye (1977) proposed the theory of complex interdependence, which highlights the decreasing use of military power as a tool of diplomacy amidst the increasing use of various forms of cooperative interdependencies amongst nations(Keohane \& Nye 1977). Amidst the era of globalization, states maximize their national interests through non-violent forms of cooperation with other states. In other words, cooperation through institutions, including international human rights law, demonstrates the increasing convergence of aggregated preferences and interests of involved states. For instance, using the case study of European institutions, Andrew Moravscik (1995) argues that the success of such institutions is predicated upon nations that already guarantee basic human rights. In other words, these supranational human rights institutions reinforce the already preexisting national preferences of member-states. Beth Simmons (2012), meanwhile, underscores the importance of various non-state human rights stakeholders in reinforcing the effectiveness of international human rights law. Another study undermines the effectiveness of transnational human rights movements, while highlighting instead the role of preferential trade regulations that include human rights conditionalities $-\mathrm{a}$ 
policy strategy that does not only seek to bolster the political interests of its advocates but also to advance a wide variety of national interests (Hafner-Burton 2009).

In the field of comparative politics, meanwhile, scholars often focus on intranational and statist variables to account for the variation in human rights compliance across time within a given country. This comparativist literature can be roughly divided into two strands (HafnerBurton (2014, 274-276). The first strand, on the one hand, refers to the scholarly studies that refer to violent armed conflict as a key factor, as such kind of conflicts generate persistent cycles of human rights violations that, once they gain traction, are quite hard to stop. Hence, lowintensity conflicts provoke states to respond with the extensive deployment of the resources of its coercive apparatus, thereby increasing the propensity for political terror and killings of civilians. For example, the armed Islamic nationalist rebellion in southern Philippines has been a persisting conflict in ways that make it difficult for the Philippine state to balance state security with demands to respect human rights claims of unarmed civilians (Regilme 2016, 236-238). This difficulty in balancing those two policy goals became much more serious especially after the Philippines joined the US-led war on terror after the 9/11 attacks. Thus, countries that face its own enduring civil wars and violent conflicts within some parts of its territory are more likely to witness atrocities than those that have been historically peaceful (Poe and Tate 1994; Goldhagen 1996). In many cases, women and ethnic minorities are often the most vulnerable targets of state terror caught in conflict against armed rebel groups (Cohen and Green 2012).

The second strand of this literature refers to the type and form of governance system as the key predictor for the likelihood of human rights abuses. Accordingly, democratic states are more likely to promote and to comply with human rights norms than their non-democratic counterparts, primarily because such governance systems empower citizens in shaping the states' policy agenda, which in turn, makes it less likely for the government to deploy political terror upon civilians compared to authoritarian states (Poe \& Tate 1994; Cingranelli \& Richards 1999; Davenport 2007). Yet, not all democracies are the same; many non-consolidated democracies still face the persistent occurrence of election-related violence, thereby contributing to the state's inability to fully implement its human rights commitments (Hafner-Burton et al. 2013). Quite similarly, Bertrand Badie (2000) emphasizes the role of predatory state formation after the colonial period in Africa, particularly when rent-seeking postcolonial elites have persistently used the state apparatus in attracting foreign investments and aid rather than generating wealth from within the country. In that way, these postcolonial elites have been more preoccupied in generating their own private wealth rather than upholding broader public interests through the use of political violence.

This section has summarized some of the most recent and notable social scientific scholarly findings pertaining to the conditions that shape human rights outcomes. The next part of the chapter discusses some of the key contending views that support and dispute the legitimacy and effectiveness of humanitarian interventions.

\section{Humanitarian Interventions: History, Legitimacy, and Effectiveness (2,000 words)}

Is humanitarian intervention, in principle, legitimate? If so, then how and under which condition could it be legitimate? The international system that emerged after the Second World War paved the way for the supposed entrenchment of the norm of state sovereignty, but it was later on overruled through a number of landmark efforts. In fact, as the UN Charter (1945) Article 2, Section 7 clearly states: "Nothing contained in the present Charter shall authorize the United Nations to intervene in matters which are essential within the domestic jurisdiction of any state". Yet, three years after the UN Charter was ratified, the Genocide Convention (1948), with 149 ratifying and acceding state parties as of December 2017, overrode the state sovereignty 
norm by effectively legitimizing the option for any of its contracting parties to act within the UN system "for the prevention and suppression of acts of genocide" (Article 7).

In 2001, three months after the 9/11 attacks in the US, the Canadian Government formed the International Commission on Intervention and State Sovereignty (ICISS) in reaction to UN Secretary General Kofi Annan's international community to reflect upon the conditions of breaking state sovereignty for humanitarian reasons. The ICISS formulated the doctrine of 'responsibility to protect' (R2P), which posits that individual states both have the right to primarily shape its domestic affairs and the obligation to promote the welfare of people within its borders - and, in cases where the state fails to fulfill such an obligation, the international community should step in (ICISS 2001; United Nations 2013). Hence, the R2P doctrine maintains that any given state has the original but non-exclusive obligation to promote the security and welfare of its inhabitants within its territory. It is non-exclusive because the broader global community should fill in that role in cases of the concerned state's failure of doing so (Acharya 2002, 273-274). Thus, for the ICISS, the principles of sovereignty and humanitarian intervention should be treated as complementary instead of being antithetical to each other (MacFarlane, Thielking, and Weiss, 2004, 978). More precisely, a state's claim for sovereignty is conditional upon observance of basic standards of human rights and its effectiveness to uphold its citizens' welfare. Although the norms of non-intervention and sovereignty are established principles, Michael Doyle (2015) maintains they can be abrogated in cases of enduring civil wars, prevention of mass massacres, and possibly, for post-war peace building initiatives.

Moreover, some scholars studying international norms contend that the rise of global human rights norms, especially after the Cold War in the 1990s, have facilitated the increasing legitimization of R2P (Walling 2015, 387). Yet, building the case that the target state has been fully engaged in extensive human rights violations of its own people serves as an important task for R2P advocates. Although such interventions are usually framed as an acceptable enforcement mechanism of international human rights law, critics claim that interveners, in practice, may further deteriorate the human rights situation in target states through sanctions, invasions, and even the imposition of authoritarian forms of governance (Cohen 2008, 580).

In practice, the UN Security Council (UNSC) serves as the focal multilateral institution responsible for the authorization and coordination of humanitarian interventions, with the explicit aim of aiding a multilateral coalition that would protect civilians caught in an armed conflict in a target state. It was in April 2006 that the UNSC officially referred to the R2P doctrine when it passed resolution 1674 that reaffirms the international community's collective responsibility to uphold the rights of civilians in cases of armed conflicts. Following that landmark resolution, the UNSC passed on succeeding resolutions that embody the R2P response in regard to several humanitarian problems, including Libya (2011), Côte d'Ivoire (2011), Yemen (2011), South Sudan (2011), Syria (2012) (United Nations, 2013).

The ethical claims and justifications that underpin militaristic forms of humanitarian interventions remain highly contentious. Arguments in support of or in opposition to humanitarian intervention can be roughly defined across disciplines, particularly in international law, philosophy, and political science (Teson and Vossen 2017, 8). In general, scholars of international law oppose humanitarian intervention except in cases that are fully authorized by the UNSC; philosophers generally favor it, under certain conditions, as exemplified in the just war literature; and political scientists are quite divided on the issue.

A general theme that divides advocates and oppositionists of humanitarian intervention refers to the clash between state sovereignty and human rights (Bellamy 2010). Supporting interventions, solidarists claim that the contemporary international society has nurtured a common set of beliefs pertaining to the key elements that characterize a humanitarian disaster. For that reason, this common understanding develops over time, and states do not possess unconditional claim to sovereignty considering that its authority can be abrogated in grave humanitarian emergencies that require some forms of external military intervention. Failure to 
intervene in such cases could not only detrimentally undermine the welfare of civilians in the concerned states; rather, a grave humanitarian disaster is likely to have dangerous spillover effects to regional security.

Pluralists dispute the solidarists' foundational claim that the international community has developed a widely accepted common understanding of what constitutes a humanitarian disaster. Instead, pluralists highlight the considerable diversity of ethical standards across societies worldwide, and a purported common understanding within the international society does not exist. The R2P doctrine, which often functions as the foundational justification for militaristic humanitarian intervention, problematically implies powerful states' ill-conceived privileged position to arbitrarily position themselves as "saviors" of civilian victims often found less powerful states. Particularly, that doctrine makes a hierarchical distinction within the international system between supposedly independent sovereign states "whose citizens have political rights, and de facto trusteeship territories whose populations are seen as wards in need of external protection" (Mamdani 2010, 53). In other words, humanitarian interventions reinforce the problematic notion of 'the white man's burden' in supposedly improving the welfare of non-white individuals (MacFarlane, Thielking, and Weiss 2004; Mutua 2002). More often than not, state sovereignty remains the only compelling justification of weak states (and individuals residing therein) from unjust interventions from more powerful states, and when exceptions to that norm of sovereignty are granted, the likelihood of the instrumentalization of interventions for geostrategic and economic gains increases. Even in cases when UNSC authorization is granted, the UNSC's decision does not necessarily reflect the broad approval of the majority of the states worldwide. Powerful states still control the UNSC, and the norm of sovereignty could be the foundational norm that small states use to deter abusive and powerful states from using humanitarian reasons in intervening for the sole purpose of enhancing geostrategic or economic interests. As such, David Chandler $(2001,24)$ criticizes post-Cold War interpretations of humanitarian principles for they are now being deployed to legitimizing military sanctions and bombings that often undermine the welfare of the very people that are supposed to be protected.

Regardless of one's position in this debate, the question on how to assess the moral plausibility of humanitarian interventions remains important amidst an ongoing public interest amongst policy elites in the global North. There are three key considerations, namely: timing, intention, and scope of interventions (Teson and Vossen 2012). In terms of timing, a key question for scholars and policy-makers is to determine when exactly is the best time to determine the permissibility of a just war in the context of humanitarian interventions. Specifically, the consequentialist view maintains that the legitimacy of any militaristic humanitarian intervention can only be determined after it has been launched and when its consequences to the target state and the civilian population have been fully assessed. The contrarian view, however, asserts that the moral permissibility can only be rightfully assessed before launching an intervention, and such an assessment should constitute evidence-based forecast of its consequences. Second, another benchmark includes the intention or the just cause for launching a humanitarian intervention. What is the predominant motivation for the intervening state/s? How and under which conditions do those states ensure that humanitarian goals remain dominant in their intervention strategy? Finally, the scope of intervention needs to be seriously considered as well. Specifically, this key issue refers to the parameters and the exact implementation strategy of a given humanitarian intervention. Which actors and institutions will be involved in the intervention? Under which conditions will the intervention be implemented? In cases that interventions further aggravate the situation of civilians in the target state, what are the operational protocols of interveners?

This section has provided a brief yet comprehensive overview of humanitarian intervention's historical background, legitimating justifications, and the conditions in which it could be morally permissible. Moreover, this section also highlighted some of the practical and 
political arguments that oppose militaristic interference in the name of supposedly humanitarian goals. Moving forward, the next section provides an overview of some of the key challenges to the contemporary global human rights regime.

\section{Contemporary challenges to the global human rights regime (1,500 words)}

Whereas the end of the Cold War in the 1990s paved the way for the optimistic view that democracy and human rights could be the "end of history" (Fukuyama 1992), the start of the 21" century, however, witnessed a backsliding from what seems to be political gains that were accumulated in the previous decade. There are two key phases in global politics that ushered in this contemporary crisis in human rights. The first constitutive element of this crisis refers to the global military insecurity that was fueled by the $9 / 11$ terror attacks in the US. Consequently, the Bush administration and other US allies launched the global 'war on terror', which facilitated the growth of the US security apparatus and militaristic approaches to armed conflicts worldwide (Priest \& Arkin 2011). Apparently inspired by the political thoughts of Leo Strauss and neoconservatism (Hirst 2013), many proponents of the Iraq War under the Bush administration advocated for democracy promotion abroad while actively espousing US national interest through the use of violence and military force. Consequently, the idea that state security takes precedence over individual physical integrity rights gained some traction amidst the public anxiety caused by non-state terror attacks. The second constitutive element concerns the 2007/2008 global financial crisis, which further accelerated the neoliberalization of many advanced economies of the world vis-à-vis the continued weakening of the welfare state tradition in the global North. These outcomes in the political economy have radically undermined the socio-economic rights of individuals amidst growing inequality within and between nations. Taken together, the crisis of human rights, as it is often concretely attributed to the rise of Trump and authoritarian and illiberal politicians elsewhere, remains one of the key challenges not only for practitioners of emancipatory politics but also to scholars of International Relations.

In the field of human rights research, scholars seem to be divided as to the causes of this crisis. Amidst the rise of Trump and authoritarianism, taking stock of the gains and losses of the global human rights regime becomes an important scholarly undertaking. On the one hand, the optimistic view defends the global human rights movement from its critics, particularly by highlighting the movement's legitimacy and effectiveness. More recently, Kathryn Sikkink (2018), a leading political scientist working on human rights, contends that, contrary to what critics say, the emergence of the international human rights movement was facilitated by key political actors from the global North and South - a position that seeks to refute critics' claim that human rights are purely Western-centric(Sikkink 2017). Sikkink, furthermore, underscores the remarkable effectiveness of the human rights regime by emphasizing the dramatic reduction of over-all violence and fewer human rights abuses now than before. In other words, respect for human rights over the last four decades have substantially improved, and the ratification of the UN Convention Against Torture greatly contributed to such an improvement (Fariss 2014). In addition, Sikkink explains that the perception of worsening human rights violations globally could be attributed to three factors: information paradox, cognitive bias, transforming standards of accountability. More concretely, international human rights organizations have played a critical role in documenting and widely informing the public about various human rights abuses. This broad public consciousness about such abuses facilitates the negative public perception that abuses are more pervasive, as more information about it becomes more and more accessible. This sense of accessibility to information creates a negativity bias, and it also pushes individuals to increase their standards for human rights accountability. Hence, Sikkink cautions that those psychological biases should be blamed for 
the erroneous view that the global human rights regime has been incapable of making tremendous improvements in people's lives.

That sort of optimism shared by Sikkink is what many pessimistic observers have disputed. Specifically, several scholars posed some considerable criticisms against the effectiveness and legitimacy of international human rights law, institutions, and movements. For instance, Yale historian and legal scholar Samuel Moyn offers a more cautionary and pessimistic assessment of the international human rights regime(Moyn 2018a; Moyn 2018b). His main argument maintains that the current global human rights regime is insufficient for it has unfortunately abandoned the quintessential demand for material equality. Historically, various societal demands for addressing material insecurity animated the French Revolution and even the formation of the human security paradigm spearheaded by the United Nations Development Programme. This abandonment for material equality was quickly replaced by the demand for material sufficiency, which is the minimalist and compromised demand facilitated by neoliberalism. In other words, neoliberalism engendered the current tragedy of increasing material inequality, while tragically replacing an egalitarian notion of human rights with the minimalist version, that is, the demand for mere material sufficiency. Similarly, the International Relations scholar Stephen Hopgood (2013) upholds that the global human rights regime is on the verge of decay primarily because of two reasons: the use of human rights by interventionist liberal states for their own geostrategic, material interests and the rise of nonWestern powers that could fundamentally challenge the US hegemonic version of human rights (see also Regilme and Parisot 2017). The Chicago-based legal scholar Eric Posner adopts a legal rationalist-realist perspective in casting his less optimistic assessment of the global human rights regime. Posner underscores the very high expectations placed on international human rights treaties vis-à-vis the serious enforcement difficulties of enforcing those often-conflicting human rights values.

Despite the disagreements on whether the current human rights regime is generally effective in promoting the over-all welfare of individuals, several political scientists have recently propounded some proposals for the regime's eventual reform. The most notable among these perhaps comes from Emilie Hafner-Burton (2014), who controversially argues that more international human rights legal instruments might not be necessary; rather, a group of advanced democracies - or, what she calls as 'steward states' - are important in strategically addressing (or 'triaging') the most important human rights problems (instead of all types of problems). Of course, that proposal came in before the rise of Trump and the increasing influence of illiberal far-right political parties in Europe - a notable political transformation that undermines the viability of Hafner-Burton's proposal. On the other hand, Salvador Santino Regilme (2018c) suggests a three-pronged strategy: (1) emphasizing an inclusivist and pluralist conception of human dignity; (2) rewriting the rules of global economic governance in ways that uphold global justice; (3) institutionalizing mandatory political education on human rights and dignity. Advocating a more bottom-oriented and constructivist notion of human rights making, political theorist Benjamin Gregg (2016) proposes a cosmopolitan human rights state that does uphold a more process-oriented, deliberative, non-coercive process-making of thinking about and practicing human rights(Gregg 2016).

Notwithstanding one's view on the current state of the global human rights regime, there are several global trends that are worth considering. First, the rise of Trump in the US and the illiberal populism in Europe constitute a much broader global trend, whereby democracy is apparently in retreat. According to the 2018 Freedom House report, over the twelve-year period since 2006, 113 countries recorded a net decline in the quality of democracy and only 62 have registered a net improvement. For the 2018 report, with 195 countries evaluated, only 45 percent ( 88 countries) of the total number of countries were deemed as 'free', 30 percent (58 countries) partly free, and 25 percent (45 countries) not free. In other words, the majority of the world's population live in societies in which political freedoms are constrained, if not totally 
repressed. Second, income inequality has grown in almost all regions of the world in the past few decades, albeit at varying speeds, while inequality in wealth distribution has worsened. According to Oxfam, the richest $1 \%$ of the globe enjoyed $82 \%$ of the new wealth created in 2017 and $0 \%$ has went to the world's poorest $50 \%$, while close to four billion people constitute the majority of the population that live in extreme levels of poverty. The increasing levels of material inequality within nations could increase the prospects for instability and eventual collapse of contemporary political systems (Regilme 2014a). Meanwhile, the more pronounced material stratification between nations is more likely to precipitate legitimation problems for the world order - if not total revamp of the international system should those inequalities left unmanaged. Third, the increasingly pervasive use of social media networks undermines digital privacy rights of its users. Fueled by Edward Snowden's surprising leak of top-secret documents that revealed the massive global surveillance programs that US spy agencies have been leading, the debate on digital privacy rights continues especially amidst the prospects of the growing tide of authoritarianism. Specifically, the increasing accessibility to digital technologies makes it easier for abusive governments to use digital information in ways that detrimentally manipulate public behavior, or worse even kill or violently repress any form of political dissidence.

This section underscores some of the current transnational problems that the global human rights regime is facing. The next section briefly discusses some of the key information sources and datasets that are helpful for conducting social scientific research on human rights and humanitarian interventions.

\section{Datasets on human rights and humanitarian interventions}

In empirical human rights research, several datasets have emerged as useful sources of evidence for comparative cross-national research on human rights. Such datasets can be useful in analyzing the degree of change in a specific human rights aspect over time as well as between and within countries. One of the most prominent and pioneering datasets refers to the Cingranelli-Richards (CIRI) Human Rights Data Project, which annually rates the level of compliance of 202 countries with 15 globally recognized human rights. Those rights in the CIRI dataset include freedom from enforced disappearances, extrajudicial killings, torture, women's economic rights, freedom of religion, among many others. The measurement ratings range on a scale of zero to two, as zero refers to the very frequent violations of the specific rights under inquiry, while two pertains to the absence of any reported abuse. The CIRI dataset derives its ratings from the coding system that is used to read the annual reports from the US State Department and Amnesty International.

Meanwhile, the Political Terror Scale (PTS) is another useful dataset that provides an annual measure of state-initiated political terror in a given country, based on a five-level 'terror scale'. The measurements came from a coding system based on the annual reports from the US State Department, Amnesty International, and Human Rights Watch. A score of one pertains to a situation wherein the state consistently observes the rule of law, political imprisonment and torture remain very rare, and political murders seem to be very unusual. In the other extreme point of the scale, a score of five denotes that the state widely employs political terror to the entirety of the population and violently kills and abuses political dissidents.

The third notable dataset refers to the Uppsala Conflict Data Program (UCDP) by the Peace Research Institute Oslo (PRIO) and the Uppsala University's Department of Peace and Conflict Research. This dataset contains comprehensive information on armed conflicts and organized violence between and within nations, starting from the year 1946 until the present. Various important human-rights related data can be extrapolated from the UCDP, and they include statistical and geographically-based information on battle-related deaths inflicted by states, para-military forces, and armed non-state rebel groups. 
In contrast to cross-national human rights research, a high-quality and comprehensive dataset on humanitarian interventions has yet to fully emerge in contemporary political science. Yet, there are some new initiatives worth considering; particularly, the German Peace Research Institute Frankfurt (PRIF) is currently developing a dataset on humanitarian military interventions since 1945 .

\section{Conclusions}

The preceding assessment of contemporary human rights research has several key implications and insights. First, contemporary research in IR and comparative politics - as the two key subfields of political science-have substantially focused on the causes and consequences of physical integrity rights as well as civil and political rights. Amidst growing material inequality and hierarchical stratification amongst various identity-based groups, further empirical research has to be conducted on other types of rights such as socio-economic rights and its broader structural causes and consequences. Second, much of the comparative and multicountry research on human rights have shown some correlational findings, whereby specific rights have been found to be correlated to a particular variable (e.g. foreign aid, trade, corruption). Future studies may need to explore such correlations while also focusing on the causal mechanisms that link those variables. Third, the contemporary political science research on human rights has emphasized the structures of power relations within and across societies as key analytic perspectives for understanding human rights outcomes and behavioral patterns. Yet, political science may also benefit from some of the human rights-related research findings produced by other fields, including psychology, anthropology, communication studies, among others. Those fields focus at micro-level, particularly at the individual level, and focusing on the micro-level could provide some new insights as to why particular individuals conform or deviate from specific human rights norms. Moreover, political science research on humanitarian interventions has yet to produce a reliable, cross-national dataset on humanitarian military interventions. Next, although historians of human rights recently accomplished some pathbreaking research that shows the indispensable role of Global South actors in the formation of the contemporary global human rights regime, political science has yet to fully integrate these findings in teaching and research. Also, empirical political science on human rights has to fully explore the ethical assumptions and implications of its research, and a vibrant conversation between normative theorists and empirical researchers could help towards that goal. Finally, human rights norms have proven to be the language of less powerful agents in speaking for justice and advancing their interests against more powerful and exploitative institutions; yet, the recent rise of illiberal populism and authoritarianism has also shown how the language of human rights can be instrumentalized in ways that undermine the dignity of the powerless people.

\section{References}

Ayoob, M., 2002. Humanitarian Intervention and State Sovereignty. The International Journal of Human Rights, 6(1), pp.81-102.

Acharya, A. 2002. Redefining the dilemmas of humanitarian intervention. Journal of Intervention and Statebuilding, 56(3), 373-381.

Badie, B., 2000. The Imported State: The Westernization of the Political Order, Stanford, CA: Stanford University Press.

Borgwardt, E., 2007. A New Deal for the World: America's Vision for Human Rights, Cambridge, MA: Harvard University Press. 
Chandler, D.G., 2001. The Road to Military Humanitarianism: How the Human Rights NGOs Shaped A New Humanitarian Agenda. Human Rights Quarterly, 23(3), pp.678-700.

Cingranelli, D. \& Richards, D., 1999. Respect for Human Rights after the End of the Cold War. Journal of Peace Research, 36(5), pp.511-534.

Cohen, D.K. \& Green, A.H., 2012. Dueling incentives: Sexual violence in Liberia and the politics of human rights advocacy. Journal of Peace Research, 49(3), pp.445-458.

Cohen, J., 2008. Rethinking Human Rights, Democracy, and Sovereignty in the Age of Globalization. Political Theory, 36(4), pp.578-606.

Davenport, C., 2007. State repression and the domestic democratic peace, New York : Cambridge University Press.

Downs, G.W., Rocke, D.M. \& Barsoom, P.N., 1996. Is the good news about compliance good news about cooperation? International Organization, 50(3), pp.379-406.

Doyle, M. W. (2015). The Question of Intervention: John Stuart Mill and the Responsibility to Protect. New Haven: Yale University Press.

Fariss, C.J., 2014. Respect for Human Rights has Improved Over Time: Modeling the Changing Standard of Accountability. American Political Science Review, 108(02), pp.297-318.

Fassin, D., 2012. Humanitarian Reason: A Moral History of the Present, Berkeley; Los Angeles; London: University of California Press.

Fukuyama, F., 1992. The end of history and the last man, United States: The Free Press.

Goldhagen, D., 2007. Hitler's Willing Executioners: Ordinary Germans and the Holocaust, New York: Knopf.

Gregg, B., 2016. The Human Rights State, Philadelphia: University of Pennsylvania Press.

Hafner-Burton, E., 2009. Forced to Be Good: Why Trade Agreements Boost Human Rights, Ithaca and New York: Cornell University Press.

Hafner-Burton, E.M., 2014. A social science of human rights. Journal of Peace Research, 51(2), pp.273-286.

Hafner-Burton, E.M., 2013. Making Human Rights a Reality, Princeton, New Jersey: Princeton University Press.

Hafner-Burton, E.M., Hyde, S.D. \& Jablonski, R.S., 2013. When Do Governments Resort to Election Violence? British Journal of Political Science, 44(01), pp.149-179.

Hirst, A. 2013. Leo Strauss and the Invasion of Iraq: Encountering the Abyss. New York: Routledge.

Hopgood, S., 2014. Challenges to the Global Human Rights Regime: Are Human Rights Still An Effective Language for Social Change? Sur - International Journal of Human Rights, 20, pp.67-75.

Hopgood, S., 2013. The Endtimes of Human Rights, Ithaca, New York: Cornell University Press.

ICISS/International Commission on Intervention and State Sovereignty. 2001. The Responsibility to Protect: Report of the ICISS. Ottawa: International Development Research Centre.

Jensen, S.L.B., 2017. Putting to rest the Three Generations Theory of human rights. Available at: https://www .openglobalrights.org/putting-to-rest-the-three-generations-theory-of-humanrights/ [Accessed August 20, 2018].

Jensen, S.L.B., 2016. The Making of International Human Rights, Cambridge: Cambridge University Press.

Keck, M.E. \& Sikkink, K., 1998. Activists Beyond Borders: Advocacy Networks in International Politics, Ithaca, NY: Cornell University Press.

Keohane, R.O. \& Nye, J.S., 1977. Power and interdependence: world politics in transition, New York: Little, Brown, and Company.

Klose, F., 2015. The emergence of humanitarian intervention: three centuries of "enforcing humanity." In F. Klose, ed. The Emergence of Humanitarian Intervention. Ideas and Practice from the Nineteenth Century to the Present. Cambridge: Cambridge University Press, pp. 128. 
Krasner, S.D., 2010. Revisiting “The Second Image Reversed.” Paper prepared for a conference in honor of Peter Gourevitch, University of California, San Diego, April 23-24, 2010, p.17.

MacFarlane, S.N., Thielking, C.J. \& Weiss, T.G., 2004. The responsibility to protect: is anyone interested in humanitarian intervention? Third World Quarterly, 25(5), pp.977-992.

Macklem, P., 2015. What are human rights? Moral, political, legal theory. Oxford University Press Blog. Available at: https://blog.oup.com/2015/12/what-are-human-rights-moralpolitical-legal-theory/ [Accessed August 5, 2018].

Mamdani, M., 2010. Responsibility to Protect or Right to Punish? Journal of Intervention and Statebuilding, 4(1), pp.53-67.

Mearsheimer, J.J., 1994. The false promise of international institutions. International Security, 19(3), pp.5-49.

Moravcsik, A., 1995. Explaining International Human Rights Regime: Liberal Theory and Western Europe. European Journal of International Relations, 1(2), pp.157-189.

Moyn, S., 2018a. A Powerless Companion: Human Rights in the Age of Neoliberalism. Law and Contemporary Problems, pp.1-25.

Moyn, S., 2018b. Not Enough: Human Rights in an Unequal World, Cambridge and London: Harvard University Press.

Mutua, M. 2002. Human Rights: A Political and Cultural Critique. Philadelphia: University of Pennsylvania Press.

Newman, M., 2009. Humanitarian Intervention: Confronting the Contradictions, London: Hurst and Company.

Perugini, N. \& Gordon, N., 2015. The Human Right to Dominate, New York: Oxford University Press.

Poe, S.C. \& Tate, C.N., 1994. Repression of Human Rights to Personal Integrity in the 1980s: A Global Analysis. American Political Science Review, 88(4), pp.853-872.

Posner, E. 2014. The Twilight of Human Rights Law. New York City: Oxford University Press.

Priest, D. \& Arkin, W.M., 2011. Top Secret America: The Rise of the New American Security State - Dana Priest, William M. Arkin - Google Books, New York: Little, Brown, and Company.

Regilme, S.S.F.J., 2014a. Bringing the Global Political Economy Back In: Neoliberalism, Globalization, and Democratic Consolidation. International Studies Perspectives, 15(3), pp.277-296.

Regilme, S.S.F., 2014b. The Social Science of Human Rights: The Need for A "Second Image" Reversed? Third World Quarterly, 35(8), pp.1390-1405.

Regilme, S. S. F. 2016. Why Asia's Oldest Democracy is Bound to Fail. Journal of Developing Societies, 32(3), 220-245.

Regilme, S.S.F.J. \& Parisot, J., 2017. Introduction: American hegemony - global cooperation and conflict. In J. Parisot \& S. S. F. J. Regilme, eds. American Hegemony and the Rise of Emerging Powers. Cooperation or Conflict. Abingdon and New York, pp. 3-18.

Regilme, S.S.F., 2018a. Does US Foreign Aid Undermine Human Rights? The "Thaksinification" of the War on Terror Discourses and the Human Rights Crisis in Thailand, 2001 to 2006. Human Rights Review, 19(1), pp.73-95.

Regilme, S.S.F. 2018b. A human rights tragedy: Strategic localization of US foreign policy in Colombia. International Relations, 32(3), pp. 343-365.

Regilme, S.S.F., 2018c. The global politics of human rights: From human rights to human dignity? International Political Science Review, https://doi.org/10.1177/0192512118757129

Risse, T., Ropp, S.C. \& Sikkink, K., 2013. The Persistent Power of Human Rights: From Commitment to Compliance T. Risse, S. C. Ropp, \& K. Sikkink, eds., New York City: Cambridge University Press. 
Risse, T., Ropp, S.C. \& Sikkink, K., 1999. The Power of Human Rights: International Norms and Domestic Change T. Risse, S. C. Ropp, \& K. Sikkink, eds., Cambridge, UK: Cambridge University Press.

Rodogno, D., 2011. Against Massacre, Princeton: Princeton University Press.

Sikkink, K., 2017. Evidence for Hope: Making Human Rights Work in the 21st Century, Princeton: Princeton University Press.

Sikkink, K., 2011. The Justice Cascade: How Human Rights Prosecutions Are Changing World Politics, New York and London: W.W. Norton \& Company.

Sikkink, K. \& Kim, H.J., 2013. The Justice Cascade: The Origins and Effectiveness of Prosecutions of Human Rights Violations, Annual Review of Law and Social Science 9(1), pp.269-285.

Simmons, B.A., 2009. Mobilizing for Human Rights, Cambridge and New York: Cambridge University Press.

Simms, B. \& Trim, D.J.B., 2011. Towards a history of humanitarian intervention. In B. Simms \& D. J. B. Trim, eds. Humanitarian Intervention A History. New York City, pp. 1-25.

Teson, F. \& Van Der Vossen, B., 2017. Debating Humanitarian Intervention: Should We Try to Save Strangers, New York: Oxford University Press.

Tsutsui, K. \& Hafner-Burton, E.M., 2005. Human Rights in a Globalizing World : The Paradox of Empty Promises. American Journal of Sociology, 110(5), pp.1373-1411.

United Nations. 2013. The Responsibility to Protect: Background Note. Retrieved 2018, from http://www.un.org/en/preventgenocide/rwanda/pdf/Backgrounder\%20R2P\%202013.pdf

Walling, C.B., 2015. Human Rights Norms, State Sovereignty, and Humanitarian Intervention. Human Rights Quarterly, 37(2), pp.383-413.

Waltz, S., 2002. Reclaiming and rebuilding the history of the Universal Declaration of Human Rights. Third World Quarterly, 23(3), pp.437-448.

Welsh, J., 2004. Introduction. In J. Welsh, ed. Humanitarian Intervention and International Relations. New York: Oxford University Press, pp. 1-10. 